\title{
- Therapeutic challenges in treatment of a restrictive cardiomyopathy due to hypereosinophilic syndrome in a young patient: a case report
}

\author{
Nina Jakuš*, \\ Ivo Planinc, \\ Hrvoje Jurin, \\ Marijan Pašalić, \\ Dora Fabijanović, \\ Daniel Lovrić, \\ Boško Skorić, \\ Jure Samardžić, \\ Jana Ljubas Maček, \\ Hrvoje Gašparović, \\ Bojan Biočina, \\ Maja Čikeš, \\ Davor Miličić
}

University of Zagreb School of Medicine, University Hospital Centre Zagreb, Zagreb, Croatia

\begin{abstract}
KEYWORDS: hypereosinophilic syndrome, cardiac thrombus, echocardiography.
\end{abstract}
CITATION: Cardiol Croat. 2017;12(4):139-140. | https://doi.org/10.15836/ccar2017.139

*ADDRESS FOR CORRESPONDENCE: Nina Jakuš, Klinički bolnički centar Zagreb, Kišpatićeva 12, HR-10000 Zagreb, Croatia. / Phone: +385-91-5605-795 / E-mail: nina.jakush@gmail.com

ORCID: Nina Jakuš, http://orcid.org/0000-0001-7304-1127 • Ivo Planinc, http://orcid.org/0000-0003-0561-6704 Hrvoje Jurin, http://orcid.org/0000-0002-2599-553X • Marijan Pašalić, http://orcid.org/0000-0002-3197-2190 Dora Fabijanović, http://orcid.org/0000-0003-2633-3439 • Daniel Lovrić, http://orcid.org/0000-0002-5052-6559 Jana Ljubas Maček, http://orcid.org/0000-0001-7171-2206 • Boško Skorić, http://orcid.org/0000-0001-5979-2346 Jure Samardžić, http://orcid.org/0000-0002-9346-6402 • Hrvoje Gašparović, http://orcid.org/0000-0002-2492-3702 Bojan Biočina, http://orcid.org/0000-0003-3362-9596 • Maja Čikeš, http://orcid.org/0000-0002-4772-5549 Davor Miličić, http://orcid.org/0000-0001-9101-1570

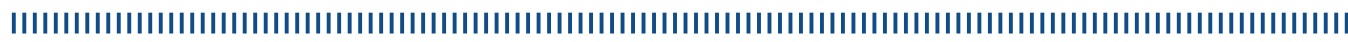

Background: Hypereosinophilic syndrome is a hematologic disorder characterized by an elevated eosinophil count in the peripheral blood and eosinophillic infiltration of other organs, resulting in end organ damage ${ }^{1,2}$. Such eosinophilic infiltration of the heart may result in the development of a restrictive cardiomyopathy, leading to symptomatic heart failure.

Case report: The patient was 23 years old at the time of diagnosis, previously a healthy young man His initial complaint was exertional dyspnea, paroxysmal nocturnal dyspnea and peripheral edema. Laboratory findings revealed a significantly elevated eosinophil count (41\% of the total number of leu-

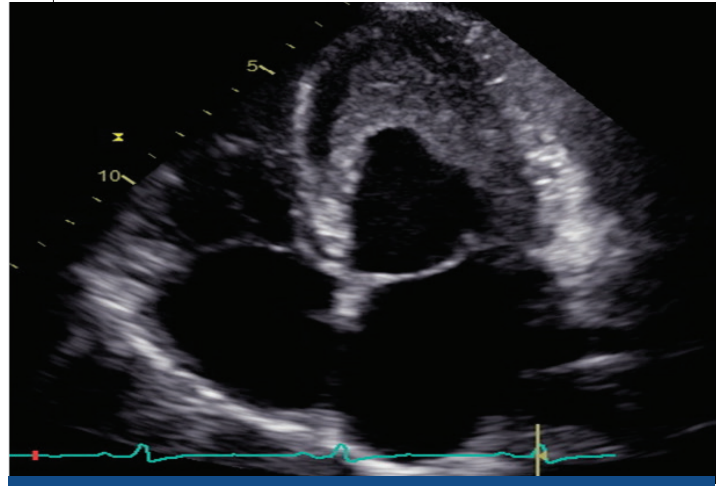

FIGURE 1. Initial echocardiogram indicating the existence of a thrombus formation in the apex of the left ventricle.

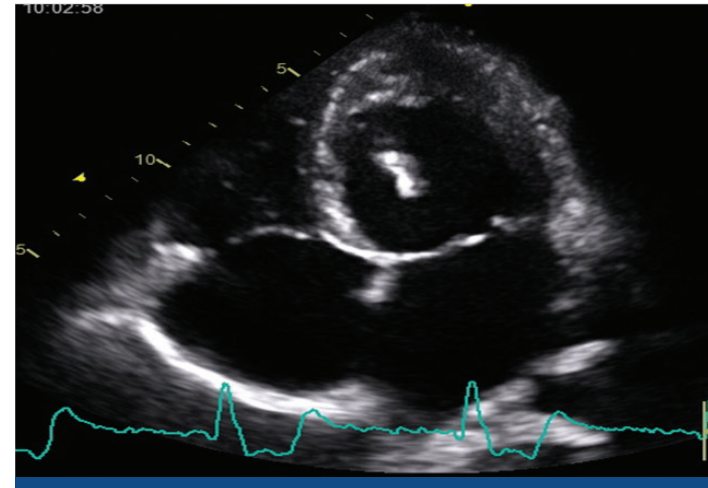

FIGURE 2. Follow up echocardiogram performed after $\mathbf{7}$ months of treatment, showing a significant reduction in the overall size of the thrombus mass, but also a peduncular formation protruding into the ventricle.
RECEIVED:

March 11, 2017

ACCEPTED:

April 6, 2017

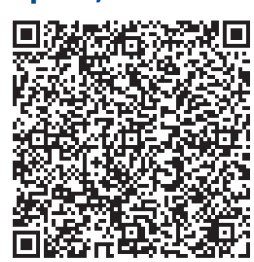

kocytes), as well as elevated levels of NT-proBNP (3784 pg/mL). He was then referred to our center from a local hospital. Initial echocardiographic examination revealed a slightly dilated left ventricle, with signs of a restrictive cardiomyopathy. Apical 4 chamber view revealed that the apex of the left ventricle is obliterated by a substance, suspected a thrombus formation (Figure 1). Magnetic resonance performed with gadolinium contrast revealed diffuse fibrosis of the endocardium and a severely hypokinetic apex of the left ventricle, filled with a thrombus mass (dimensions: $2.7 \times 2.5 \mathrm{~cm}$ ), concluding that the finding is characteristic for endocardial fibroelastosis. In coordination with a hematologist, the patient was started on imatinib, for the eosinophilia, and low molecular weight heparin, as well optimal medical treatment for heart failure. During one of the scheduled checkups, a follow up echocardiographic examination revealed a significant reduction in the overall size of the thrombus mass, but now, with a peduncular formation protruding into the ventricle, moving freely in the blood current (Figure 2). At that time, the patient had exhibited a significant clinical improvement, and was regularly 
Therapeutic challenges in treatment of a restrictive cardiomyopathy due to hypereosinophilic syndrome in a young patient: a case report

undertaking physical activity. Due to a significant embolization risk, he was urgently referred to cardiac surgery, where a successful surgical excision of the thrombus formation was performed, through a medial sternotomy.

Conclusion: Thrombus formation in patients with restrictive cardiomyopathy due to hypereosinophilic syndrome has been previously described in literature ${ }^{3}$. On the other hand, complications of treating such thrombus mass are rarely described. This case report stresses the need for close echocardiographic monitoring during the dissolution of such large thrombus masses, anticipating potential embolic complications.

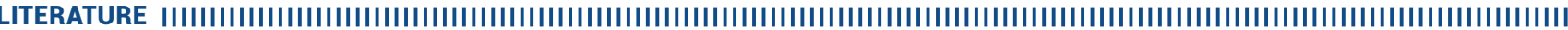

1. Butt NM, Lambert J, Ali S, Beer PA, Cross NC, Duncombe A, et al; British Committee for Standards in Haematology. Guideline for the investigation and management of eosinophilia. Br $J$ Haematol. 2017 Feb;176(4):553-572. https://www.ncbi.nlm.nih.gov/pubmed/28112388

2. Mankad R, Bonnichsen C, Mankad S. Hypereosinophilic syndrome: cardiac diagnosis and management. Heart. 2016 Jan;102(2):100-6. https://doi.org/10.1136/heartjnl-2015-307959

3. Baqi A, Waheed S, Tipoo FA, Khan AH. Biventricular thrombus in hypereosinophilic syndrome presenting with shortness of breath. Turk J Emerg Med. 2016 May 8;16(2):83-85. https://doi.org/10.1016/j.tjem.2015.05.002 